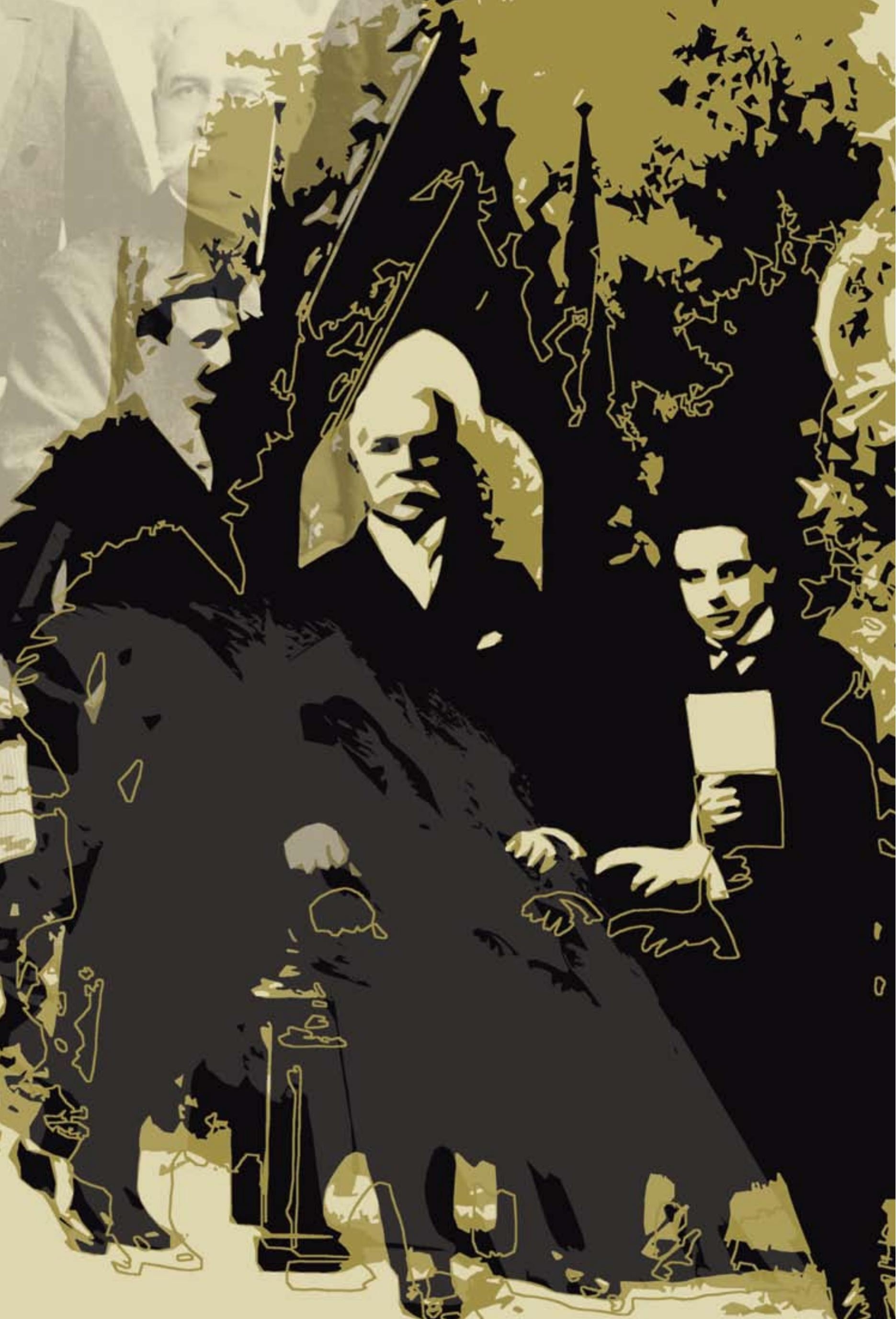


MARCO AURÉLIO NOGUEIRA

\section{Joaquim Nabuco}

\section{Da Abolição}

à diplomacia, 


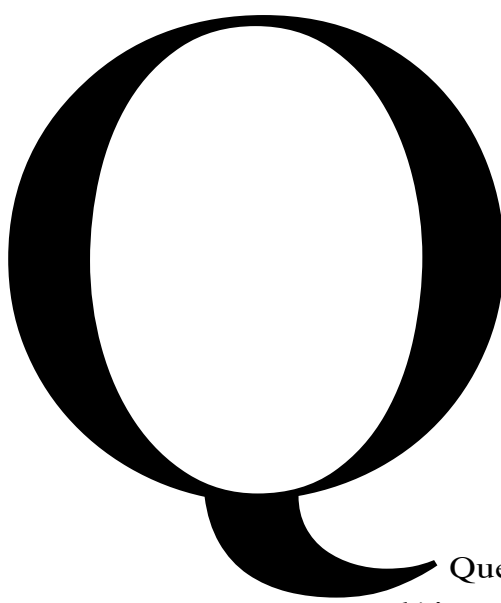

uase cem anos depois de sua morte

- ocorrida em janeiro de 1910 , quando era embaixador brasileiro nos Estados Unidos -, Joaquim Nabuco permanece a despertar interesse, a nos intrigar. Como compreender isso?

lítico, diplomata, intelectual e pessoa? Que dimensão de sua complexa e sinuosa biografia deve ser tomada como base para um diálogo teórico com aquilo que pensou, escreveu e realizou? Que papel efetivo desempenhou na história brasileira, que legado nos deixou?

Agitador e ideólogo abolicionista, deputado liberal monarquista, diplomata pan-americanista, Nabuco equilibrou-se sobre múltiplas pernas, cumprindo distintas tarefas e abraçando causas aparentemente contraditórias. Ainda em vida, deu margem a interpretações conflitantes de sua trajetória e de suas escolhas. Foi visto como "incendiário" na campanha pela Abolição, como reacionário pelos republicanos empolgados com o golpe de 15 de Novembro, como europeísta e aristocrata - um inglês em terras tropicais - e como porta-voz ingênuo dos interesses estratégicos dos Estados Unidos, um "pan-americanista do Norte", na frase cortante de Oliveira Lima. Depois da morte, e sobretudo mais tarde, com a expansão das pesquisas acadêmicas dedicadas à sua contribuição, as águas continuaram turbulentas, ainda que embaladas por uma mesma onda forte de respeito e admiração.

Com quantos Nabucos temos de lidar? Como compreendê-los e unificá-los? Com qual Nabuco devemos dialogar?

Antes de tudo, convém começar reconhecendo que o caráter multifacetado do personagem reflete bem as circunstâncias em que atuou, bem como a qualidade dos roteiros a que se submeteu. Poder-se-ia dizer que a realidade social concreta foi ela mesma sinuosa, arrastando consigo muitas personalidades e impondo a elas agendas desprovidas de lógica ou concatenação. Em sua racionalidade, a história desafiava os atores, forçando-os a realizar manobras de risco, a fazer opções inesperadas, a mudar de campo e posição como que em busca de um eixo de sustentação.

O próprio percurso político e intelectual de Nabuco confirma essa impressão. Não há como captar de um só golpe a surpreendente evolução daquele aristocrata refinado que, de um quase republicanismo na adolescência, passou sem vacilações para o monarquismo parlamentar, tornou-se abolicionista militante nos anos 80 , depois federalista, releu em termos conservadores seu próprio liberalismo após a queda da Monarquia, reencontrou-se com a religião para então se proclamar pan-americanista, num zigue-zague que ele próprio sempre procurou justificar.

Nabuco parece ter-se incomodado com a transição que marcou sua vida e o levou do "politeísmo da mocidade" para a "volta misteriosa e indefinível da fé" nos anos 1890, como ele escreveu em Minha Formação. Esforçou-se para entender e explicar a conversão do seu liberalismo social da década abolicionista no liberalismo conservador do período posterior à queda da Monarquia, a flutuação constante entre o cosmopolitismo mundano e o engajamento nacional, a dúvida entre a literatura e a política. Passou a vida tentando justificar a sinuosidade de sua evolução.

Nabuco foi um cidadão do mundo, encantado com a dimensão universal da aventura humana. Viveu muito mais próximo das agitações do espírito e da imaginação do que da prosaica rotina política ou administrativa. Cresceu como um dândi, com presença ativa nos salões da corte brasileira. Num certo trecho da estrada, envolveu-se com a política. Dedicou-se a ela, porém, de modo contido, estilizado e passional, como se quisesse neutralizar a face mais diabólica do poder e deixar claro seu desinteresse pelo jogo político miúdo, frio e calculista. Amadureceu no interior da luta abolicionista, na qual ocupou lugar de destaque com um liberalismo combativo, 
disposto a descer às catacumbas sociais para interpelar as senzalas e reformar a sociedade. Ficou desorientado com a derrocada da Monarquia em 1889, quando então, aos 40 anos, hibernou por uma década para tentar encontrar um eixo com que se relançar na vida pública. Encontrou-o na diplomacia.

Paralelamente a essas inflexões, Nabuco foi um escritor talentoso, de estilo envolvente, autor de livros, artigos e ensaios indispensáveis para que se compreenda a formação social brasileira. Sua obra não saiu de cena ao longo do século XX e chega ao século XXI com potência suficiente para dialogar com os analistas interessados em entender o processo que levou o Brasil à modernidade.

Nabuco nos surpreende, intriga e confunde, em segundo lugar, porque sua biografia, sua obra e seu percurso espelharam a história brasileira em um de seus mais emblemáticos momentos: o efervescente período de 1870 a 1910, com seu entrecruzamento de desenvolvimento e crise, mudança e "revolução", no qual foram se sucedendo e se combinando a decomposiçãoda ordem colonial, a passagem para a República, a substituição da preponderância inglesa pela norte-americana, os novos tipos sociais que se constituíam nas cidades que cresciam e se agitavam. Aquela foi uma época em que o Brasil disputou uma partida na qual estava em jogo seu destino na história universal. As seis décadas de vida de Nabuco (1849-1910) não chegaram a produzir tudo o que anunciaram, mas foram anos repletos de promessas e possibilidades. Anos movimentados, que contaminaram e excitaram todos os que pretenderam, de algum modo, neles se inserircomo protagonistas, em maior ou menor grau.

Ao longo dessa trajetória, as convicções e os engajamentos de Nabuco se alteraram, assim como suas ênfases e opções, a tal ponto que o primeiro impulso do historiador é constatar a existência de mais de um Nabuco, quase uma personalidade dividida, composta por personas antagônicas ou ao menos distintas entre si. Na sua tradução mais fácil e conhecida, tal impulso tem levado à contraposição do Nabuco "radical" da campanha abolicionista - vibrante, empolgante, capaz de levantar multidões com discursos arrebatadores - ao Nabuco diplomata da maturidade, mais um conservador que um liberal, limitado a esperar o fim da vida com intervenções mais seletivas e menos passionais, ainda que não menos destacadas.

Sem desmerecer o caráter persuasivo e a função explicativa dessa perspectiva de análise, que se apoia em fatos e inflexões inscritas na biografia do personagem, gostaria de sustentar, no presente texto, uma distinta linha de argumentação ${ }^{1}$. Minha hipótese é que a personalidade multifacetada de $\mathrm{Na}$ buco jamais esteve solta no ar, desamarrada ou arrastada às cegas pelas circunstâncias históricas e por seus dilemas pessoais. Ela refletiu por certo essas circunstâncias e esses dilemas, mas sempre esteve animada por um mesmo tipo de relação com o mundo e por uma mesma concepção ideal, que deram unidade e articulação à sua biografia.

Tratou-se sempre de um mesmo e único personagem, portador de um liberalismo suficientemente elástico para acompanhar as mudanças históricas. Se houve radicalismo na primeira fase e conservadorismo na última, isso se deveu em boa medida ao próprio padrão do liberalismo brasileiro, aos ritmos do processo social e aos novos desafios que se impuseram aos intelectuais e políticos do país.

Em um primeiro momento (1870-90), tratava-se de dar direção a uma onda reformadora que crescia a partir do problema escravo e poderia ameaçar a construção do Estado nacional, fato que se confundia com a defesa da Monarquia. Mais tarde, com a República instalada, tratava-se de organizar o novo regime e de inserir o país num mundo que mudava em termos de relações internacionais e ingressava em nova etapa do capitalismo. Também aí, para Nabuco, a questão era o Estado nacional. Se na primeira fase a unidade nacional dependia da defesa de um sistema de governo (a Monarquia parlamentar), na segunda ela passa a ter valor em si, independentemente de regimes, partidos e governantes, um telos absorvente, sem o qual o futuro se comprometeria. Se, nos anos abolicionistas, o
Opresente texto incorpora passagens substantivas de dois ensaios redigidos em ocasiões anteriores (Nogueira, 2000 e 2003-07) e baseia-se na pesquisa realizada para o livro As Desventuras do Liberalismo (Nogueira, 1984). 
liberalismo foi convocado para honrar seus compromissos reformadores humanistas, no final da vida ele apareceria como alicerce moral de um Estado capaz de defender o território e a soberania para um povo-nação em constituição.

Nesse sentido, dialogarei bastante com a hipótese desenvolvida por Ricardo Salles, que, nabusca da "organicidade de Nabuco", o verá como um intelectual tradicional (Gramsci), " portador de certa autonomia em relação às classes sociais e de uma continuidade histórica". Equilibrando-se sobre os temas da cidadania, da soberania, da reforma social e da centralidade do governo na condução do país, Nabuco os articulará em torno da "questão da nação", inserindose na problemática liberal e democrática do final do século XIX (Salles, 2002, p. 23). O “equilíbrio” de Nabuco-ou seja, seu esforço para manter unidos o intelectual e o político - ficará perfeitamente explicitado nas duas grandes causas em que se empenhou ao longo da vida: a Abolição da Escravatura e a união pan-americana.

\section{INTELECTUALISMO E}

\section{PRAGMATISMO}

No agitado, dinâmico e paradoxal teatro do período 1870-1910, Nabuco evoluiu protegido por um tecido em que se entrelaçavam intelectualismoesteticizante e realismo pragmático, visão ético-moralizante e engajamento político.

A permanente tensão entre ética e política que se nota em sua trajetória derivou da própria antropologia de Nabuco, isto é, de sua concepção de homem. Ele observou em Minha Formação: "Cada um de nós é só o raio estético que há no interior do seu pensamento, e, enquanto não se conhece a natureza desse raio, não se tem ideia do que o homem realmente é" (Nabuco, 1976, p. 27). Essa "mola estética" prevaleceu sempre sobre todas as demais molas do mecanismo político e intelectual de Nabuco. Foi ela - ou seja, a imaginação, a fantasia, a bele- za da invenção, a harmonia, a coerência, a frase adequada, o estilo - que orientou suas escolhas e definiu seu caráter, embasando seja o seu parlamentarismo à inglesa, seja o seu patriotismo cosmopolita. Foi essa mola, enfim, que lhe possibilitou enfrentar o dilema comum aos intelectuais da época: como conciliar sentimento e imaginação, como ser cosmopolita, universal, humano e se inserir ativamente na vida nacional, com seu provincianismo tedioso?

No justamente famoso capítulo IV de Minha Formação, não por acaso intitulado “Atração do Mundo", Nabuco dirá que a dificuldade daquela conciliação nos condenava "à mais terrível das instabilidades". Quando em terra americana, a "perspectiva humana" não se encontrava com a paisagem, com a vida ou com a arquitetura, ao passo que o americano, na Europa, ressentia-se da falta da pátria. "De um lado do mar sente-se a ausência do mundo; do outro, a ausência do país" (Nabuco, 1976, p. 26). Tal dificuldade de conciliação acabaria por impor um desfecho:

“Quando, porém, entre a pátria, que é o sentimento, e o mundo, que é o pensamento, vi que a imaginação podia quebrar a estreita forma em que estavam a cozer ao sol tropical os meus pequenos debuxos de almas, deixei ir a Europa, a história, a arte, guardando do que é universal só a religião e as letras" (Nabuco, 1976, p. 28).

Nabuco reformulou assim parte importante das próprias convicções, atenuando o molde europeu de sua formação e acentuando sua inaptidão para a política cotidiana, miúda, rotineira.

A política prática estava em contradição com a postura espiritual cosmopolita ou, antes, mundana, que se caracterizaria “pela compreensão das soluções opostas dos mesmos problemas sociais, pela tolerância de todas as opiniões, pela igual familiaridade com correligionários e adversários, pela ideia, para dizer tudo, de que acima de quaisquer partidos está a boa socieda$d e$ ". Não se tratava de excluir ou rejeitar a política, mas de pensá-la e praticá-la a 
partir de outro ponto de vista que, sem ser necessariamente eclético, ou cético, seria "incompatível com o fanatismo, isto é, com a intolerância, qualquer que seja ela". Nabuco, por isso, colocou-se sempre "em um terreno politicamente neutro" (Nabuco, 1976, p. 30), fora e acima de partidos, de emoções tópicas e passageiras. Suas afinidades políticas mantiveram-se vivas, mas em posição secundária, "subordinadas à atração puramente intelectual” (Nabuco, 1976 , p. 33), protegidas por uma "imaginação europeia" suficientemente espessa para resistir “à política local, a ideias, preconceitos e paixões de partido, isoladora de tudo o que não pertencesse à estética" (Nabuco, 1976, p. 51).

Foi intelectualista e estetizante o engajamento de Nabuco na luta contra a escravidão. A presença dos escravos o incomodava não somente porque representava um entrave ao progresso material do país e era um fator de perturbação e rebaixamento da Monarquia, mas porque era infamante e ultrajante, colidia com as razões maiores da humanidade, relegava os brasileiros ao lixo da história e impedia sua afirmação como povo, sua cidadania e sua capacidade de autodeterminação. Tratava-se de um "problema moral", que por isso teria de ser enfrentado num terreno fortemente impregnado de parâmetros éticos e morais. Dar-se-ia o mesmo com o pan-americanismo, causa a que Nabuco se entregou no final da vida.

$\mathrm{Na}$ verdade, Nabuco quis fazer política sem ser político, abraçando bandeiras capazes de empolgá-lo, de eliminar o que a política tinha de "emoção partidária, incerta, negativa, de temor de edificar desconfiado da solidez dos materiais e do terreno" e de reter somente o que anunciasse "as auroras da verdade e da consciência sobre o mundo" (Nabuco, 1976, p. 113). Recusou-se a ser "nominalista" em política, seguindo somente a "compaixão concreta pela sorte do povo" (Nabuco, 1949b, p. 59).

Nabuco acreditou que, em todas as suas grandes emoções políticas, prevaleceu apenas "o drama humano universal transportado para nossa terra”. Sua ambição em política teria sido"toda de ordem puramente intelectual, como a do orador, do poeta, do escritor, do reformador". Dirá textualmente:

"Procurei na política o lado moral, imaginei-a uma espécie de cavalaria moderna, a cavalaria andante dos princípios e das reformas; tive nela emoções de tribuna, por vezes de popularidade, mas não passei daí: do limiar; nunca o oficialismo me tentou, nunca a sua deleitação me foi revelada; nunca renunciei a imaginação, a curiosidade, o diletantismo, para prestar sequer os primeiros votos de obediência" (Nabuco, 1976, pp. 22-3).

Em Nabuco, porém, a visão estetizante não se entregava sem luta à própria lógica. Em certa medida, era desautorizada e contrabalançada pelo empenho pragmático e realista em obter resultados, pela busca do desfecho e da conclusão. Foi assim especialmente no abolicionismo, causa que exigiu a mobilização dos fatos puros do espírito tanto quanto das impurezas da política prática, que impôs concessões e acomodações de vários tipos e levou o esteta moralizante a buscar as raízes sociais dos fatos morais, a se abrir para alianças e forças “materiais" e, com isso, a ultrapassar o plano próprio do drama, da moral, da estética. Não bastavam a indignação ética e a iniciativa intelectual, nem mesmo quando acompanhadas de alguma pressão popular. As coisas não aconteceriam naturalmente, sem determinações de vontade e sem iniciativa política-do Parlamento, dos estadistas, dos governos, da Coroa (Nabuco, 2000, pp. 39-43; cf. Nogueira, 2001).

A grande reforma social almejava ir além da libertação dos escravos. Donde a realista e pragmática indiferença de Nabuco para com a questão da forma do governo: enquanto a Monarquia estivesse contribuindo para a conclusão da reforma, teria no abolicionismo um leal aliado; discutir sua substituição pela República seria abrir mão do fundamental. O decisivo era responsabilizar o vértice estatal, convocá-lo para cumprir seu papel na magna tarefa de erradicar "a obra da escravidão". 
Do mesmo modo, o embelezamento retórico da Monarquia - eixo constitutivo de Um Estadista do Império, como se sabe - esteve compensado tanto pelo esforço “objetivo" de contar a história quanto pela preocupação de explicar a morte da Monarquia e de justificar-se a si próprio. Sua teoria monarquista foi o contraponto - quem sabe a correção de rota, a depuração, a negação - de sua teoria abolicionista. Sua última década, a do pan-americanismo, poderia ser vista, assim, como a síntese, a negação da negação.

O plano ético-moralizante do intelectualismo e o plano mais imediatamente político do realismo viveram em tensão e em equilíbrio dinâmico, alimentando-se um ao outro. Nabuco formou-se intelectualmente nos entrechoques da razão universal e da substância nacional, dos princípios puros - da Ideia - e da sua tradução prática. Chegou à maturidade e ao fim da vida às voltas com a luta entre o fascínio excitante da imaginação e a monotonia rasteira da prática política e administrativa. Quis brilhar como panamericanista, por exemplo, na primeira década do século XX, e esforçou-se para expor com convicção o que acreditava ser a mais bela ideia para um novo tempo. Foi no entanto ludibriado pela competência "prática" de Rio Branco, num embate surdo mas nunca plenamente disfarçado. Seu pan-americanismo foi "exuberante e entusiasmado", ao passo que o do barão esteve sempre cortado "pela sobriedade e pelo realismo", como escreveu Álvaro Lins (1996, p. 322).

\section{ESTILIZAÇÃO, REALISMOE DIPLOMACIA}

Atrajetória diplomática de Nabuco, bem como o modo como ele se desincumbiu das tarefas que lhe foram atribuídas pelos governos republicanos entre 1899 e 1910 , não fugiram dos traços gerais de sua personalidade política e intelectual.
Proclamada a República, Nabuco retirou-se para a vida privada. Fechou-se "em uma espécie de arquivo, a recolher em livros, em documentos, em retratos, em tradições quase desconhecidas hoje, os traços da original, delicada e a alguns respeitos ideal civilização em que pôde florescer por tanto tempo a única Monarquia da América" (Nabuco, 2002, p. 77). Entregando-se à redação de Um Estadista do Império, preparou-se discretamente para ingressar no século XX. Pouco a pouco, desfeitos os sonhos restauradores e confirmada a supremacia do civilismo paulista sobre o republicanismo militar, foi-se tornando disponível para novos engajamentos. A tensão dialética entre intelectualismo e realismo voltaria a pulsar, agora com outro molejo. Seriam outros os tempos, outras as ideias.

Passada a onda "jacobina" que acompanhou o golpe de 1889, os republicanos conseguiram cimentar um caminho para moderar a construção do país em termos políticos e sociais, liberando-o em termos econômicos. O Brasil se modernizou e se alterou bastante, mas permaneceu quase o mesmo em política. A "nova classe” que emerge com a República dotará a nação de um Estado federalizado e de uma rotina democrático-representativa administrada por cima, de modo elitista. Edificou assim uma ordem política liberal mas não democrática. A República modelou tanto as práticas políticas quanto as mentalidades e as condutas, mesmo as aparentemente mais firmes e resistentes, como a de Nabuco. Ao final da primeira década do novo regime, já não havia mais uma revolução a ser feita, e a vida política se acomodaria. Acomodarse-iam também, de modo inevitável, os alinhamentos políticos e doutrinários.

Muitos defensores da Monarquia traduziram o dilema da época numa escolha entre a nação e o regime. Com quem deveriam ficar, agora que a República se consolidara?

Nabuco pavimentou com cuidado (ainda que não necessariamente com cálculo) sua aproximação com o governo republicano. Estabeleceu em 1890 um porto seguro na ideia de que "não é preciso ser republicano 
sob a República, como não era preciso sob a Monarquia ser monarquista, para cumprir os deveres de um bom brasileiro. Basta ter clara a noção de que nunca se tem direito de prejudicar a pátria para prejudicar o governo" (Nabuco, 1949b, pp. 69-70). Liberou-se gradativamente para aceitar, em 1899, o convite feito por Campos Salles para voltar ao serviço diplomático. Escreveu então ao almirante Jaceguai:

"Podem os partidos na luta política acharme em contradição com eles; ainda não me acharam, porém, incoerente comigo mesmo, com meus próprios sentimentos, que são os ideais a que servi. [...] Não foi à última hora, foi logo desde a primeira que continuei minha marcha sob a República pela mesma estrada, a cavaleiro dos partidos, em que andei sempre sob a Monarquia" (Nabuco, 1949c, II, pp. 13-5).

A adesão de Nabuco foi pragmática. A restauração monárquica, afinal, havia ficado inviável pois se reduzira à reposição mecânica do passado. E ele, por diferentes razões, não poderia se conformar em ter os livros como sua única causa. Além do mais, era preciso dar condições de governabilidade à República dos civis contra os “jacobinos militaristas”. Ao pragmatismo, porém, não faltaria uma boa dose de estilização. Nabuco optava pela pátria, pela causa nacional, pelo dever para com o país, não pela questão política. Decidia-se motivado pelo apoio que mereciam aqueles que com ele compartilhavam muitas coisas e afinidades. Em abril de 1899, escreveu a Domingos Alves Ribeiro:

"Fui e sou monarquista, mas essa é uma caracterização secundária para mim, acidental; a caracterização verdadeira, tônica, foi outra: liberal - liberal não no sentido partidário, estreito, mas no sentido que decorre destas duas consciências profundas que tenho em mim, de criatura de Deus e de membro da humanidade. Essa é a caracterização política da minha vida, como a afetiva é a brasileira. São essas três grandes correntes morais - Deus, Pátria, Humanidade
- que formaram a zona temperada do meu liberalismo, a única em que vivi. Por isso chamaram-me na Monarquia republicanoe por isso fiquei na República monarquista" (Nabuco, 1949c, II, pp. 24-5).

A diplomacia oferecia a Nabuco todas as condições para evitar o ostracismo, o que seria, àquela altura (aos 50 anos de idade), uma morte antecipada. Permitiu-lhe entrar em sintonia com o país sem maiores exigências políticas ou ideológicas. A diplomacia estava revestida de uma auréola suprapartidária e patriótica incontestável, que deitava raízes no Império. Como reforço, fornecia

Reprodução

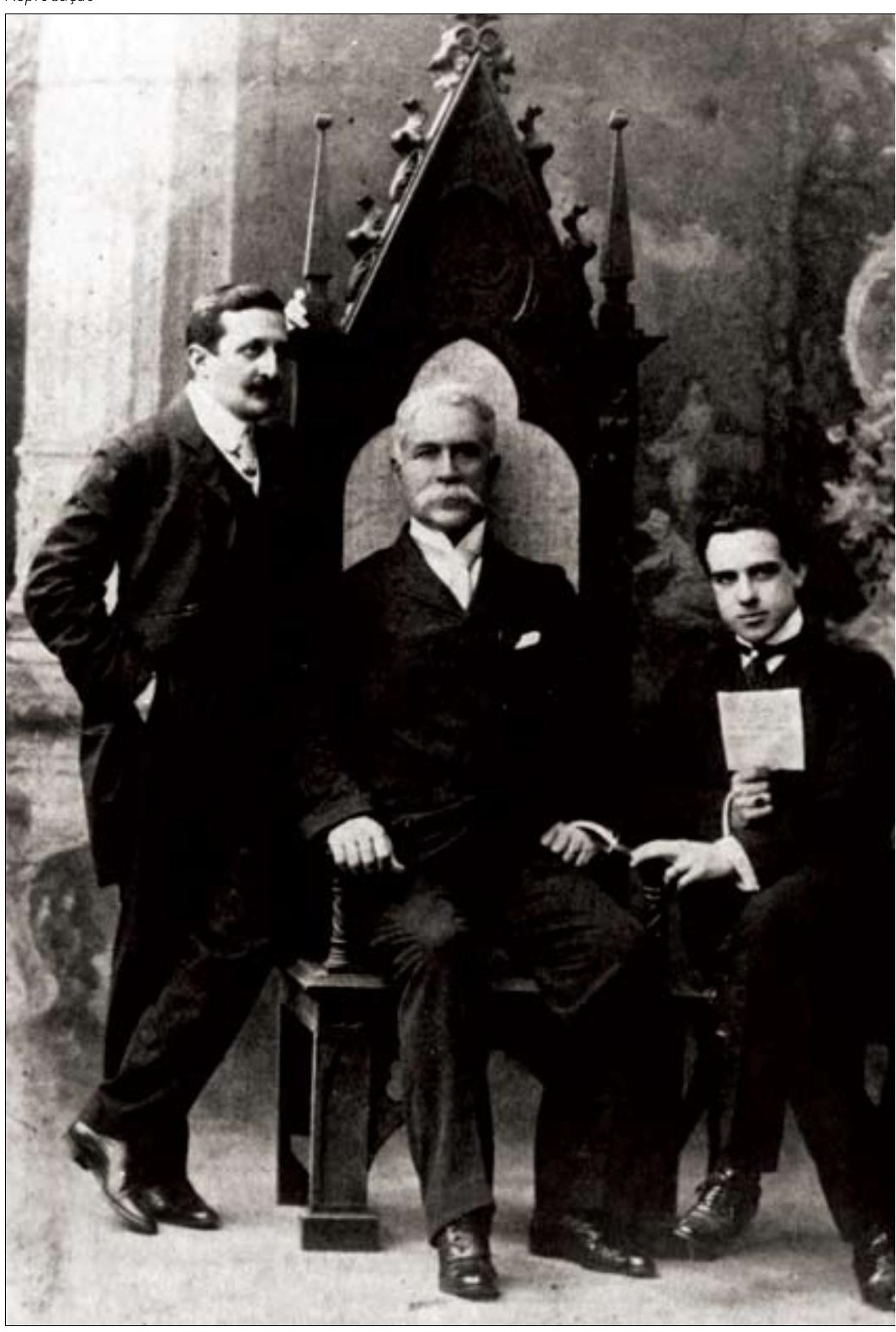

Joaquim

Nabuco com

Graça Aranha

e Carlos

Magalhães de

Azevedo,

Roma, 1904 
a Nabuco o mundo e o afastava da política miúda. Concedia-lhe um largo espaço para pelejar por ideias e ideais, para desenhar grandes projetos e voltar a desempenhar um papel de destaque.

As circunstâncias históricas o auxiliaram nesse movimento. A política externa brasileira ingressou no novo século tendo de conviver com um sistema internacional em transformação e cortado tanto pela intensificação das disputas por mercados e territórios quanto por fortes redefinições em termos de hegemonia e de preeminência. $O$ prosseguimento ascendente da marcha imperialista em escala mundial, com a consequente redefinição do equilíbrio de forças entre as grandes potências, forçaria o governo brasileiro a voltar-se para o continente americano. Era preciso buscar relacionamentos internacionais mais diversificados e paritários. O capitalismo em expansão (no mundo e no interior de cada nação) produziria uma reversão no exclusivismo europeu, incentivando ao menos um flerte com as Américas. Ainda que fortemente determinado pela emergência dos Estados Unidos como grande protagonista das relações internacionais, o movimento em direção à América também refletia a necessidade de se redimensionar o relacionamento brasileiro com os países latino-americanos, que havia sido permanente fonte de tensões ao longo do século XIX. O Brasil carecia de um novo e melhor equacionamento de suas relações externas, capaz tanto de firmar um estatuto de limites territoriais e de estabilizar politicamente a América do Sul quanto de enfrentar as novas exigências comerciais e financeiras impostas pela nova ordem econômica mundial e pela própria economia nacional.

Assumindo o Ministério das Relações Exteriores no final de 1902, o barão do Rio Branco será o grande artífice da reviravolta da política externa brasileira. Continuador das tradições da diplomacia imperial mas suficientemente flexível e moderno para perceber a nova ordem de coisas, procurará conduzir o Brasil para a conquista de um espaço próprio junto à América Latina. Buscará um inteligente equilíbrio entre a influência britânica e a influência norteamericana, aproximando-se dos Estados Unidos para contrabalançar o peso da Inglaterra e cortejando a Argentina e o Chile para conter as ambições do Norte. Tentará garantir a independência de ação brasileirae obter vantagens diante dos países vizinhos. Nem sempre obterá sucesso nessa manobra e acabará - de modo não necessariamente intencional - por ser o principal impulsionador da "americanização" da política externa brasileira.

Nabuco foi o tradutor passional da política de Rio Branco. Tornou-se um entusiasta do pan-americanismo entendido como união americana sob a ascendência dos Estados Unidos. Necessitado de uma nova causa, adotou o pan-americanismo com o mesmo ardor dos seus sonhos patrióticos da década abolicionista, como escreveu para Rio Branco em outubro de 1907. Preparou-se para isso desde a década de 1890. Em Balmaceda (1895), por exemplo, escreveu que era preciso prestar mais atenção à "marcha do continente" e ouvir a "pulsação continental", já que o Brasil passara a "fazer parte de um sistema político mais vasto”. Nesse sistema, era insensato "lutar contra o imã do Continente, suspenso, ao que parece, no Capitólio de Washington”. Converter-se-áao "monroísmo", à tese de que a política externa dos Estados Unidos não podia se submeter à vontade das nações europeias e deveria garantira segurança do continente americano (“A América para os americanos").

Nabuco fará essa conversão, porém, demarcando distância dos republicanos, que acreditavam que o americanismo era uma "força cósmica, como se o oxigênio e o azoto formassem na América uma combinação especial dotada de vibrações republicanas", uma espécie de "garantia dada não só à independência, mas à forma republicana em todo o continente". Nabuco não aceitava que se pudesse predeterminar o "modo que a civilização há de encontrar para se introduzir no Continente". Não seria seguramente mediante uma "absorção pela Europa", nem por meio de proclamações doutrinárias republicanas. Poderia ser por um monroísmo bem compreendido, que 
admitisse que "a solução do problema fosse procurada dentro mesmo de cada um dos nossos países" (Nabuco, 1937, pp. 183-6).

Seria injusto e incorreto referenciar o pan-americanismo de Nabuco a uma capitulação diante da supremacia norteamericana. Sua adesão e sua entrega àquela causa foram marcadas por um misto de ingenuidade, intuição e generosidade. Precocemente envelhecido e sem ânimo político maior, Nabuco concebeu a união americana como um verdadeiro sucedâneo do abolicionismo, um meio de superar a marginalidade política a que ele próprio se reduzira depois de 1888 . Nada mais havia que o prendesse ao passado senão o heroísmo e as glórias da campanha abolicionista. Quando retorna ao Brasil em 1906, para as sessões da III Conferência Pan-Americana, pronunciou um discurso em Belo Horizonte reconhecendo o fato: "Para preencher esse vazio profundo era preciso uma causa tão grande do ponto de vista nacional como tinha sido a causa da abolição".

O pan-americanismo foi a ponte que o ex-monarquista encontrou para chegar à República e permanecer útil ao país, ficar bem consigo e com a nação. Foi sua última propaganda, na qual realismo e estilização ainda puderam pulsar com alguma vibração.

\section{O IMÃ SUSPENSO}

Nabuco chegou aos Estados Unidos de má vontade. Não lhe interessava o modo de vida americano, tão avesso aos hábitos e valores aristocráticos que ele incorporara em seu longo convívio com a cultura europeia. Chegou saudoso do Velho Mundo, ressentido com Rio Branco, que o afastara da Europa e o enviara para uma espécie de “desterro", enterrando-o em um "pomposo túmulo” (Nabuco, 1949c, II, p. 213). Suas primeiras observações a respeito da nomeação e da ida forçada para Washington são amargas, quase depressivas.

Nabuco levava consigo algumas convicções dos anos em que fora attachée da
Legação brasileira nos Estados Unidos (1876-77) e que se cristalizaram na década de 1890. Acreditava que iria se deparar, em Washington, com a vida americana em estado bruto: pragmática, horizontal, informal, insensível à educação dos sentidos e às boas maneiras. Estava certo de que voltaria a se aborrecer, como na década de 1870, com aquele "país prático por excelência", no qual "ganhar dinheiro é o único fim real", uma sociedade mercantil com um "povo de shopkeepers" (Nabuco, 2005, I, p. 140).

Mas Nabuco era diplomata em serviçoe se esforçaria para ver o lado profissional e o lado simbólico de suas novas atribuições. Além disso, estava convencido de que o eixo do mundo se deslocara para a América do Norte, tanto em termos geopolíticos, quanto em termos culturais. Em março de 1890 , por exemplo, ele anotou em seus Diários: "a aristocracia do futuro não promete ser outra senão a do dinheiro; o cosmopolitismo argentário sobrepujou todas as nobrezas e distinções do mundo" (Nabuco, 2005, II, p. 180). Estava em curso um "processo de desmoralização geral pelo mercantilismo e dinheiro", diante do qual era preciso repor certos parâmetros mas sobretudo inovar, transformar. Ou seja, conservar para modificare avançar, ideia com a qual Nabuco fizera a luta abolicionista e que o acompanharia a Washington. Pouco depois de chegar à capital norte-americana, em 1905, escreveu a Tobias Monteiro: “É preciso um pouco de tradição, um pouco de passado, sobretudo quanto aos costumes, mas é preciso também, e muito mais, transformação, e futuro" (Nabuco, 1949c, II, p. 223).

Até mesmo por obrigação funcional, mas também por sensibilidade analítica, Nabuco percebia a preeminência que estava reservada aos Estados Unidos na nova ordem mundial em constituição. Acreditava que era preciso modificar o centro da política externa brasileira, direcioná-la para o norte. Em março de 1899, escreveu a Rui Barbosa para enfatizar que "todas as altas posições e funções políticas entre nós [...] têm dora em diante que ser aceitas sob a impressão do terror sagrado próprio aos que elaboram os destinos nacionais em uma época de crises 
e mutações" (Nabuco, 1949c, II, p. 10).

Na verdade, ele entrou no novo século convencido do desgaste dos parâmetros e instituições anteriores, como que a anunciar o início de uma era de "decadência nacional”. Dirá a Carlos Magalhães de Azevedo em fevereiro de 1899: “[...] entramos na órbita americana [...] e nossa evolução far-se-á no mesmo sentido que a dos outros satélites de Washington" (Nabuco, 1949c, II, p. 5).

Depois dos estragos provocados pelos jacobinos republicanos - que haviam deixado, na sua concepção, um país “sem

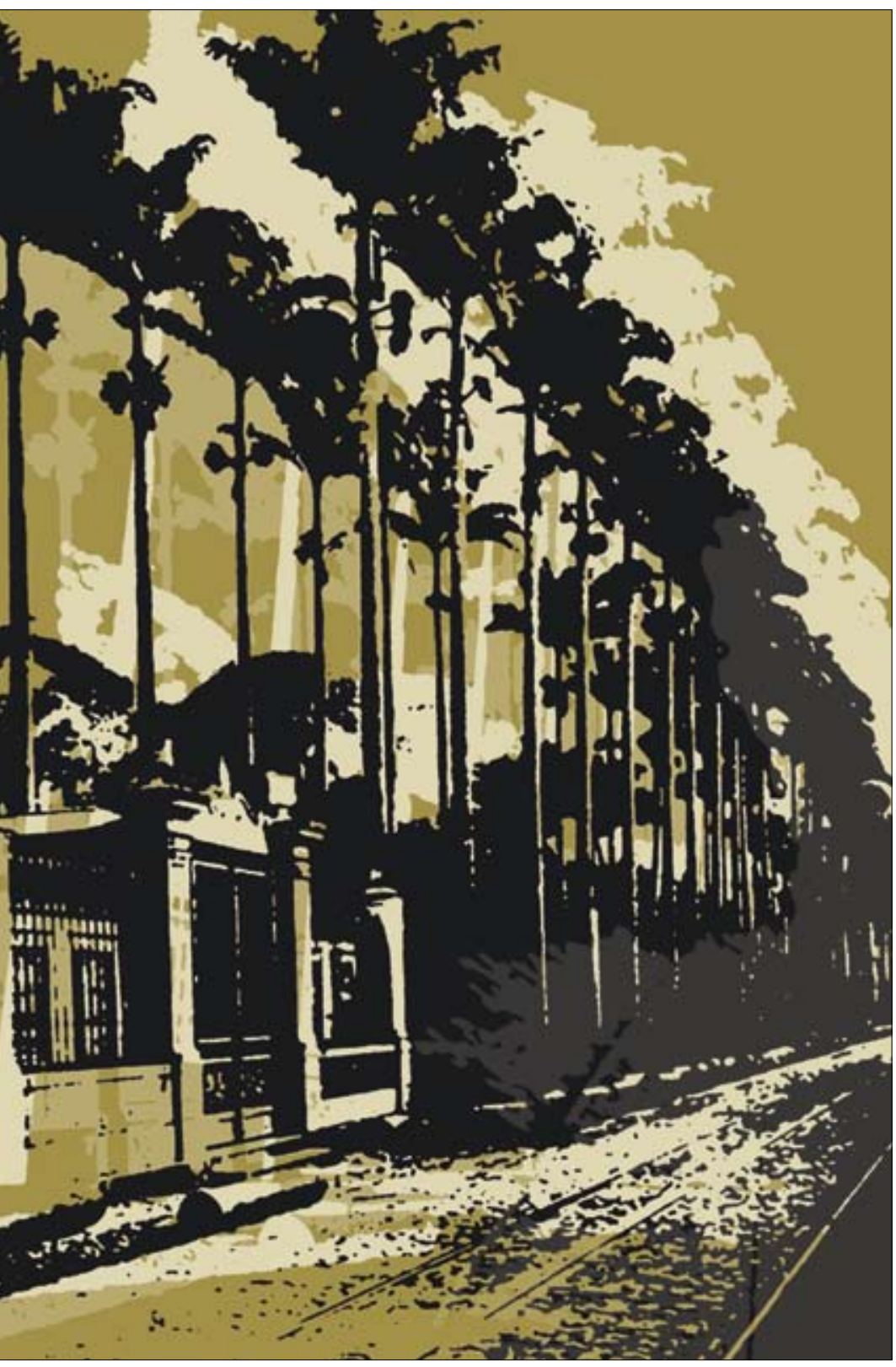

instituições dignas deste nome" - e tendo em vista a volta dos políticos civis ao comando do Estado, era chegada a hora de reorganizar o Brasil e sintonizá-lo com o novo mundo que nascia. Algo deveria ser feito para garantir a integridade territorial (o "corpo da pátria”) e organizar a nação, educar e preparar o povo para o futuro, ou seja, cuidar da "alma da pátria", como ele observou em uma carta ao almirante Jaceguai (Nabuco, 1949c, II, p. 16). Sem um "movimento patriótico irresistível", que mobilizasse as melhores energias e os maiores talentos nacionais, o país seria arrastado para o caos republicano sul-americano e não conseguiria enfrentar os novos perigos que surgiam, ameaçadores, vindos de fora. A diplomacia configurava-se, assim, como um decisivo instrumento do Estado.

Foi com essa concepção que aceitou, em 1899, depois de longo flerte, colaborar com os republicanos e ir para a Europa advogar pelo Brasil em uma disputa territorial com a Inglaterra envolvendo a Guiana. Mergulharia na diplomacia em um momento internacional que considerava delicado, perigoso, mas, por isso mesmo, excelente para altos voos de imaginação e vontade. Em 1900, é nomeado ministro-chefe da Legação brasileira em Londres. Entrega-se à redação e à propaganda da defesa brasileira, circulando pela Europa. Em 1902, com a eleição de Rodrigues Alves para a Presidência da República, Rio Branco assume o Ministério das Relações Exteriores. Em maio de 1902, escreverá de Londres com intuito de animar o amigo a aceitar o Ministério das Relações Exteriores:

“O Brasil vale bem esse sacrifício, porque o pobrezinho está precisado de homens para não mergulhar no remoinho sul-americano. Esta é uma fase crítica exceto para os grandes impérios, e ainda assim estes não sabem o que lhes vai acontecer. É a era dos trusts e dos combines" (Nabuco, 1949c, II, pp. 121-2).

As relações com Rio Branco, no entanto, não serão tranquilas. A vocação de Nabuco era a de ser protagonista. Não gostava nem 
de receber ordens, nem de se ver ultrapassado por fatos ou decisões políticas. Seu esteticismo e sua formação aristocrática o compeliam para a independência, e se chocarão com o realismo e as ponderações pragmáticas do ministro. Nabuco desejava permanecer em Londres, quem sabe em Roma ou no Vaticano, lugares-símbolo da velha Europa que tanto o encantava, e na qual imaginava se estabilizar. Rio Branco pensava diferente, e o nomeou para instalar a primeira embaixada brasileira, nos Estados Unidos.

Em janeiro de 1905, Nabuco começa a comentar com os amigos a nomeação para Washington. Suas cartas e anotações refletem um misto de preocupação pessoal, ressentimento e disposição para voltar a cumprir um papel de destaque. Engrandecia e ampliava os fatos para suportar o que entendia ser uma injustiça. Foi nomeado em um momento complicado: apesar de seu empenho, o Brasil perdera a disputa com a Inglaterra, e o vaidoso Nabuco sentira o golpe. Washington era uma oportunidade para voltar ao palco mas, simultaneamente, representava para ele um "duplo desterro", que o colocava "longe da Europa e longe do Brasil". Como escreveu a Graça Aranha, interpretava a nomeação como uma "remoção forçada", pois Rio Branco não the havia deixado nem a opção moral, nem a opção patriótica. Não podia recusar, ainda que não desejasse a embaixada (Nabuco, 1949c, II, p. 202).

Explorará então ao máximo a convicção de que se estava a entrar em um novo mundo, repleto de desafios e oportunidades. O mundo mudara, ganhara mais velocidade e mais gente. Antes, havia "menos gente e mais lazer". Ao abrir-se o novo século, passara-se a viver "em um crowd e dentro de um expresso", escreveu ao barão de Albuquerque. Momentos críticos e tensos, porém, exigiam grandes causas e grandes homens:

"É o sistema político do globo que começa em vez do antigo sistema europeu! É um grande assunto de observação tudo isso. Pode-se dizer que estamos nas vésperas de uma nova era. Para nós, o observatório de Washington é em tal conjuntura o mais importante de todos" (Nabuco, 1949c, II, pp. 199-200).

Era preciso, portanto, desde logo, "estudar a doutrina de Monroe". Não havia muita margem para alternativas. A escolha seria "entre o monroísmo e a recolonização europeia":

“O equilíbrio dos dois mundos não permite mais a existência de nações isoladas e tirando benefícios dele. Hoje a proteção impõe deveres às nações que a recebem, e a única proteção da América é o sea-power que só os Estados Unidos têm nela. Monroísmo é assim a afirmação da independência e integridade nacional pelo único sistema que as pode garantir" (Nabuco, 2005, p. 346).

Embora reconhecesse que a criação da embaixada era uma iniciativa de mérito estratégico, tinha dúvidas quanto ao caráter da decisão e às reais intenções do governo republicano. Iria para os Estados Unidos consciente da relevância norte-americana e da necessidade de se unirem as Américas. "Não nomearam um autômato, nem um antimonroísta”, escreverá a Graça Aranha em janeiro de 1905 (Nabuco, 1949c, II, 202). Não gostara inicialmente da nomeação, mas não se queixaria indefinidamente. Iria se empenhar como sempre, procurando "o modo de construir pela imaginação alguma coisa em que o país se reveja com a consciência satisfeita” (Nabuco, 1949c, II, p. 203).

Em uma famosa carta para Rio Branco, redigida em dezembro de 1905, Nabuco deixará claro o que imaginava ser sua maior contribuição e suas preocupações. "Eu acredito estar chocando para você e o Presidente um ovo de águia, mas tenho medo de que levado para aí ele saia gorado por falta de calor monroísta no governo e no país". Ela insistia para que o ministro apoiasse sem vacilação os movimentos do embaixador em Washington e não perdesse a oportunidade aberta pela Terceira Conferência Pan-Americana, cuja realização se daria no Rio de Janeiro em julho de 1906: 


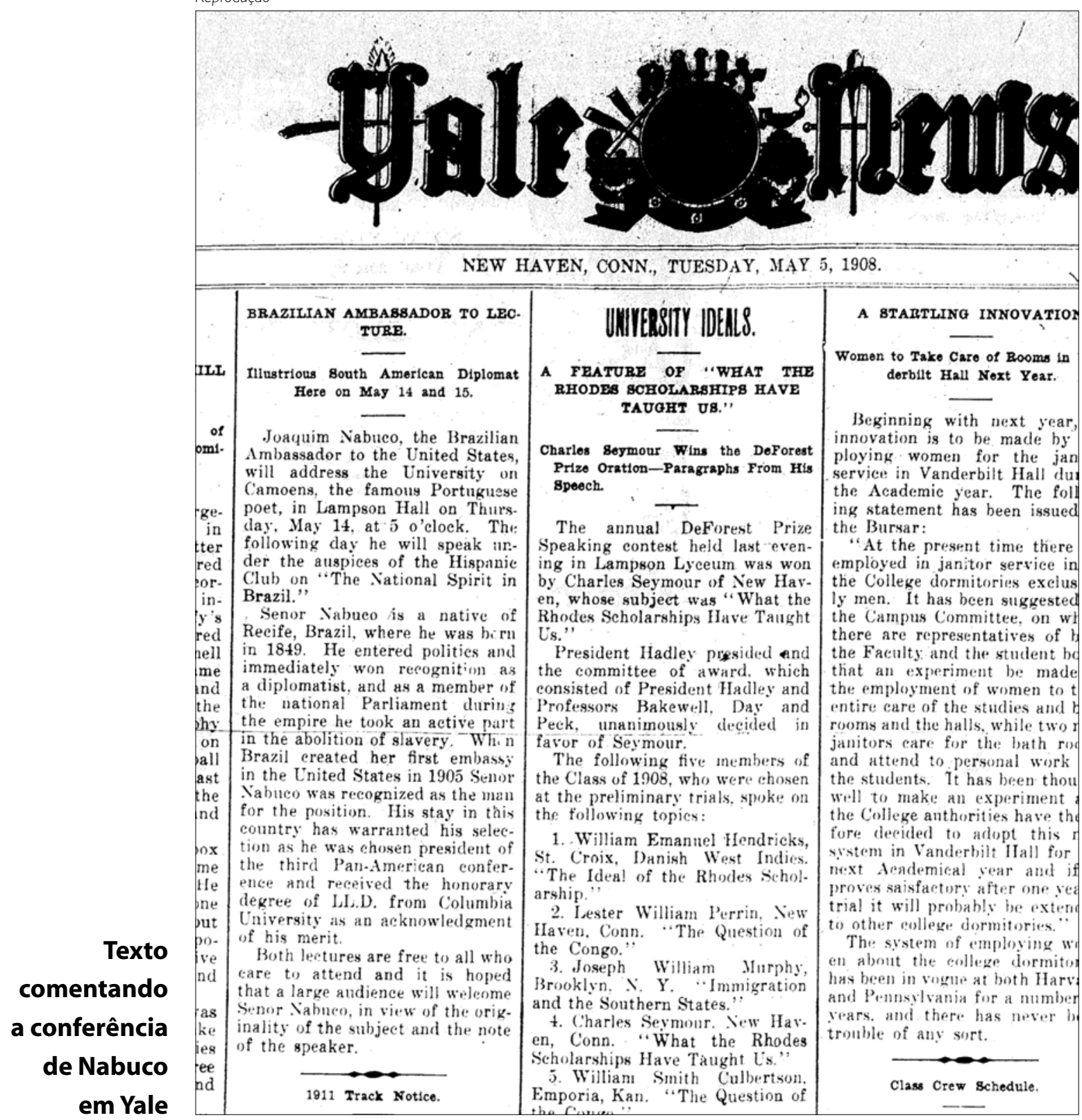

"Nunca, em minha opinião, um brasileiro teve tanta responsabilidade nos destinos do nosso país como você ante os dois caminhos que se lhe deparam: o americano e o outro, a que não sei como chamar, se de latino-americano, se de independente, se de solitário. Eu, pela minha parte, sou francamente monroísta, e é uma pena estar fazendo tanto aqui se estou trabalhando em vão, para nada. [...] O meu monroísmo é mais largo [...] o que eu quero é uma espécie de aliança tácita, subentendida, entre os nossos dois países; que vamos nesse caminho tão longe e quanto nos seja possível, e que fiquemos desde já certos um do outro. [...] Não estou trabalhando para mim. Será uma fatalidade, se nós não concordarmos em encarar o futuro do nosso país do mesmo modo, porque da concordância podia nascer um grande acontecimento, uma nova era nacional" (Nabuco, 1949c, II, pp. 237-9).

A Terceira Conferência será um sucesso político, mas a aliança tácita desejada por Nabuco não foi aprovada. Mesmo assim, um 
passo seria dado, e na prática reconhecia-se que, a partir de então, os Estados Unidos haviam se convertido no "centro motor" da política externa brasileira.

Nabuco permanecerá em Washington até o fim da vida. Progressivamente, suas condições de saúde piorarão. Continuará a ser homenageado e a fazer sucesso nos círculos diplomáticos, políticos e intelectuais da capital norte-americana. Receberá inúmeros convites para proferir conferências em círculos literários e universitários. Equilibrava-se entre a paixão intelectual e o dever profissional, que ele via como patriótico $^{2}$.

Será nesse contextoque Nabuco discursará em Yale, em 14 e 15 de maio de 1908.

\section{YALE, CAMÕES E 0 SENTIMENTO DA NACIONALIDADE}

Por que falar de Camões e dos Lusíadas nos Estados Unidos ${ }^{3}$ ?

Antes de tudo, para realçar o valor em si da língua portuguesa, num momento em que a cultura estava se "tornando cada vez mais difusamente anglo-germânica" e os autores clássicos perdiam prestígio. Camões ocupava um lugar no panteão dos grandes poetas, ainda que o idioma em que se expressava lhe trouxesse algumas desvantagens perante auditórios mais amplos.

Camões, além disso, era o "poeta da sua Nação”, fato que lhe dava extraordinário relevo mas, ao mesmo tempo, prejudicava sua recepção, já que era expressiva a "falta de interesse geral em Portugal como fator na história, como individualidade entre as nações". Exemplo grandioso de um poema nacional digno do nome, Os Lusíadas exprime um autêntico "culto da pátria”, um "santuário e relicário de Portugal", a cantar os feitos e as glórias "de um império e de um poder marítimo a constituir-se".

Para Nabuco, o épico de Camões também era "o poema da era moderna", dedicado a evocar o Ocidente que o poeta - mediante o uso genial da imaginação
- desejava ver unido em suas margens opostas, a Europa e a América. Tratavase de uma obra que buscava enobrecer e dignificar a vida, consubstanciando-se em “poesia e ação do mais alto cunho". Com seus versos, o poeta "alcançou um fim que não é dado nem aos reis nem aos estadistas alcançarem - infundir vida imorredoura à alma de seu povo".

Falar de Camões e dos Lusíadas para norte-americanos, no início do século XX, naquele momento em que se desenhava um novo mapa político no mundo, cujo epicentro seria ocupado precisamente pelos Estados Unidos, era portanto mais que prestar homenagem a um gênio poético. Era também cantar as glórias da pátria e acima de tudo de uma ideia de pátria: era explicitar o valor da nacionalidade, do sentimento nacional, do território e, ao mesmo tempo, da imaginação e da vontade, sem as quais seria impossível construir boas sociedades.

Valendo-se das metáforas camonianas, Nabuco queria destacar a missão que se impusera, anos atrás (em 1905), ao aceitar a tarefa de criar a embaixada brasileira em Washington. Desejava dar sua contribuição para que os norte-americanos conhecessem e admirassem o valor dos mitos, dos heróis, dos monumentos mediante os quais se fundara o outro lado da América, o lado do sul, mais precisamente o Brasil.

Esse propósito ficou claro na conferência do dia seguinte, 15 de maio de 1908 , proferida no Spanish Club da Universidade de Yale e intitulada, não por acaso, “O Sentimento da Nacionalidade na História do Brasil”. Nabuco quis falar do Brasil depois de ter falado de Camões "porque o Brasil e os Lusíadas são as duas maiores obras de Portugal".

Como o poema, também o Brasil ganhava voo impelido pelo idealismo, do qual fazia parte o americanismo. Nabuco declarou na conferência: "Somos e sempre fomos leais ao nosso continente. O Brasil nunca poderia acorrentar-se a funções interesseiras ou egoístas, pois é governado pela imaginação". Tudo deveria ser visto por esse ângulo.

\footnotetext{
2 Sobre a dimensão mais propriamente biográfica de Nabuco, em suas diferentes fases e com muitas de suas questões cotidianas, ver: Viana Filho, 1973; Nabuco, 1929; e Alonso, 2007.

3 As conferências feitas por Nabuco nas universidades americanas, entre 1908 e 1909, estão reunidas em Pensamentos Soltos.
} 


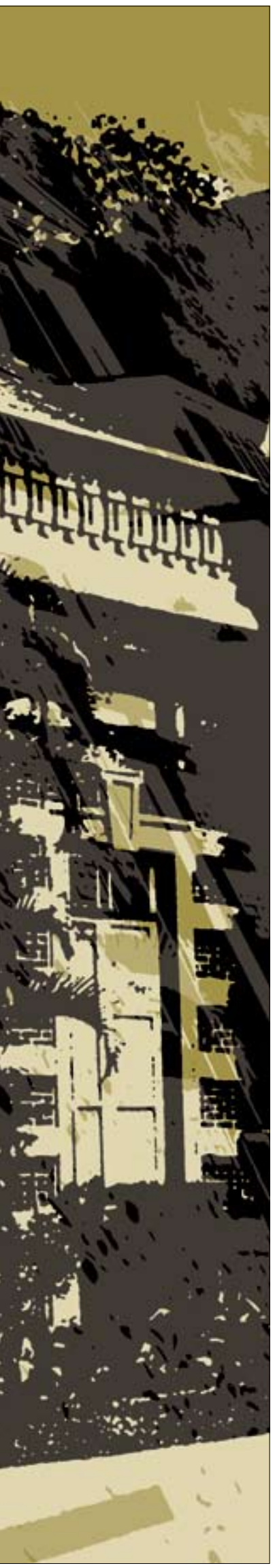

"Cada gesto da nossa história pode-se explicar pelo idealismo e por nada mais, especialmente os grandes eventos - a Independência, a Abolição da escravatura, a República -, que desabrocharam sem nódoa de sangue, por causa do idealismo nacional que faz adormecer os interesses prejudicados e as decepções de lucro, por maiores que sejam, quando se trata de um destino da Nação que precisa consumar-se" (Nabuco, 1949a, p. 442).

A República, portanto, que no passado recente tanto incomodara o embaixador, era assim celebrada em chave patriótica, selando o modo como Nabuco fizera as pazes com os republicanos. No fundo, para ele, a derrubada do trono refletira "o ideal que sempre parecera à juventude brasileira o alvo político mais desejável”, ou seja, "o da democracia sem o princípio hereditário a encabeçá-la” - ideal esse que espelhava a "ininterrupta atração exercida pelo poderoso imã suspenso no Capitólio de Washington".

Inspirado por tais fatos e valores, o Brasil organizou-se como uma nação na qual "jamais a liberdade foi sacrificada à ordem”. Soube preservar seu território e sua unidade graças à amizade com os demais países, ao catolicismo, ao idioma comum e ao sentimento nacional, atributos a que se somariam diversas circunstâncias felizes. “O Brasil sempre teve consciência do seu tamanho e tem sido governado por um sentimento profético do seu futuro. Mostrou-o como Nação desde o primeiro dia, tomando para si a categoria de império, enquanto Portugal, a antiga mãe-pátria, permanecia reino" (Nabuco, 1949a, p. 440).

O embaixador cumpriria assim seu papel. A união pan-americana teria um parceiro natural no Brasil, sempre "leal a seu continente", e contribuiria para que se introduzisse, no mundo, uma perspectiva de maior harmonia entre ordem e liberdade. Não era uma causa destinada a ter ressonância popular, como a Abolição, mas seguramente não se tratava de um súbito raio estético, descolado da realidade, estranho à lógica dura da política.

\section{CONCLUSÃO}

Não deixa de ser curioso perguntar como foi possível que alguém que manteve com a política uma relação quase de estranhamento tenha podido representar um papel político.

Pode-se supor que Nabuco beneficiou-se precisamente de seu talento doutrinário e de uma sempre desejada inserção na vida mundana para conviver tanto com a monotonia da rotina política e administrativa quanto com a modorra nacional. Alcançou um equilíbrio dinâmico entre "estética" e realismo (Nogueira, 2000) que o imunizou contra certos traços perversos da sociedade imperial - como a constante bajulação do poder, a cooptação, os jogos de cena, o arrivismo, o simulacro - e lhe possibilitou estabelecer uma zona suportável de engajamento e militância. Ajudou-o, além do mais, a embelezar e a dar maior coesão doutrinária à necessária dureza da realpolitik. Não foi um fato sem consequências ou de pouca relevância. Registrar e explorar esse equilíbrio, portanto, é um expediente analítico revestido de alta potência explicativa.

Desse equilíbrio dinâmico derivou, por exemplo, um padrão de liberalismo: espasmódico, ora heroico e vibrante, empenhado em sacudir a nação em "seu leito de paralítica", como ele diria na campanha abolicionista, ora quase ultramontano, conservador, preso à moderação contemplativa e com reduzidadimensão reformadora. Nada a lamentar, porém, sobretudo se se considerar o liberalismo brasileiro da época: "bragantino", temente, despojado de inspirações igualitárias e democráticas, concentrado muito mais na liberdade da nação (ou do sistema político nacional) que na liberdade do indivíduo ou na projeção de um futuro de maior justiça social para o país.

O equilíbrio dinâmico também impediu que o realismo pragmático bloqueasse a análise radical eabrangente. Ao invés de tolhê-lo, a "imaginação europeia" (o monarquismo parlamentar) deu a Nabuco condições de evitar o politicismo dos republicanos - presos à questão da forma do regime. Ajudou-o 


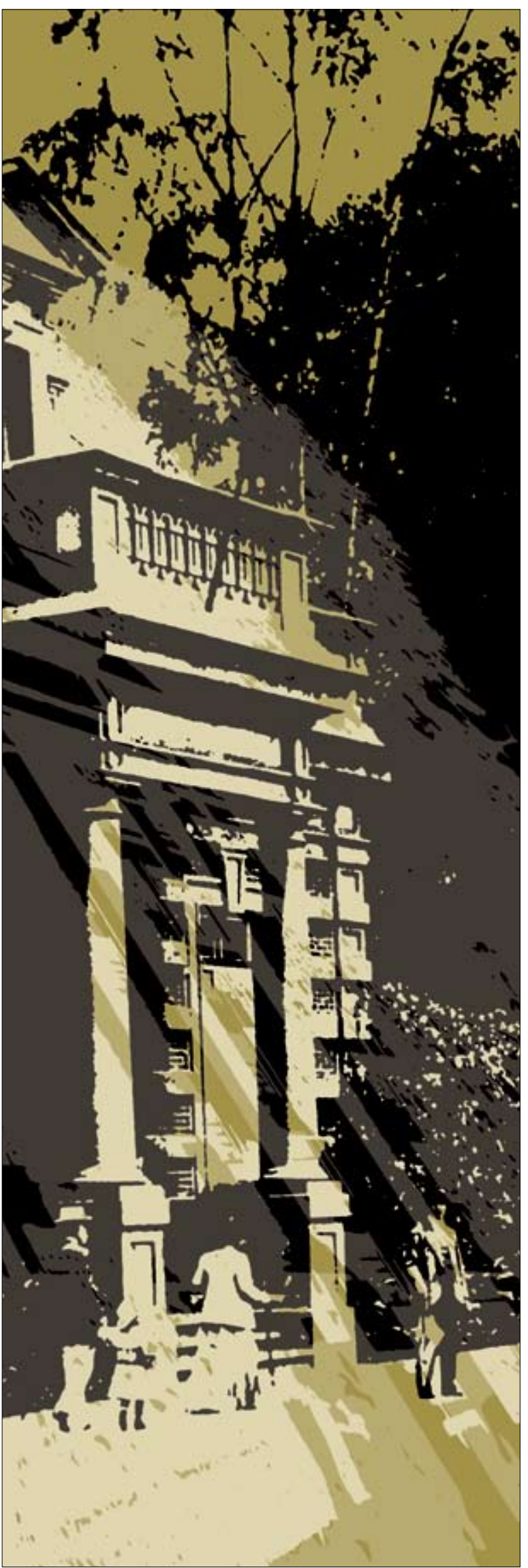

também a pensar a Abolição como reforma global. O resultado foi excepcional: ao longo da campanha abolicionista, Nabuco devassou a sociedade imperial, desceu às entranhas do sistema social organizado com fundamento na escravidão e na grande propriedade agrária, bem como apresentou um generoso plano de reformas voltadas para o desenvolvimento e o progresso social do país.

Passou-se o mesmo com sua conversão pan-americanista, ao final da vida. Ainda que em posição de menor destaque se comparada à de Rio Branco, sua movimentação não só soube focalizar uma exigência da realidade - o deslocamento do eixo da hegemonia mundial e a necessidade que tinha a política externa brasileira de acertar o passo com os Estados Unidos -, como também mostrou sensibilidade para dar "poesia" à reorientação diplomática que seria empreendida. Nabuco não teve condições de dar maior consistência teórica à política externa brasileira, mas é inegável que ele, com sua vaidade e seu entusiasmo romântico muitas vezes ingênuo, estava pensando e estilizando o que o ministro das Relações Exteriores definia como política de Estado.

Nabuco percorreu sem cessar uma trilha em cujas extremidades estacionaram o liberalismo conservador e o radicalismo liberal, o republicanismo como ideia e a Monarquia parlamentar como modelo ideal. Seu republicanismo foi exclusivamente ideal, uma “ilusão" de juventude sem maior desdobramento prático. Nabuco foi bem mais liberal que republicano e, tirando a década abolicionista, foi mais termidoriano que democrático, mais preso à beleza universal da fórmula centrista e parlamentarista que ao calor das ruas. No fundo, foi mais parlamentarista que monarquista, até mesmo porque não visualizou um modo factível (realista) de reunir regime republicano e parlamentarismo nas concretas condições históricas nacionais. Não teve como evitar a condenação do instituto da escravidão (uma indignidade que maculava a estética liberal) nem como deixar de aderir ao monarquismo. Como monarquista, porém, fez oposição ao imperador, denunciou a farsa do parlamentarismo e aceitou colaborar, ao final dos anos

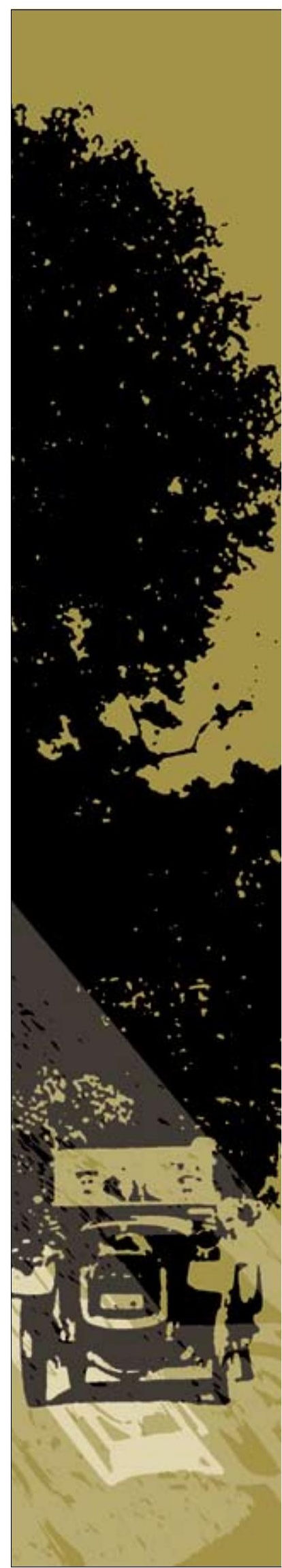


90, com a República vencedora. Proclamouse então um monarquista platônico, como se reconhecesse que os fatos tinham mais força que a ideia mas não seduziriam tanto quanto ela. Enfeixando tudo, uma nítida sensação de inoperância política.

A tensão aqui mencionada não se fazia por escolha ou opção pessoal. Ela estava em boa medida sobredeterminada pelos próprios termos do jogo social brasileiro - com sua ausência de sujeitos coletivos e cidadania ativa - e pelos próprios traços biográficos do personagem, por sua história de vida. Nabuco sempre oscilou entre as letras e a atividade prática, entre a contemplação e a ação, entre a imaginação e o sentimento, e em boa medida não teve como evitar a política, que lhe foi praticamente "imposta" por contingências familiares.

Nabuco foi, em suma, um cosmopolita que em dado momento aderiu a uma causa nacional. O fascínio pelo mundo ajudou-o a mitigar o tédio diante do ritmo nacional, mas também o afastou dele. Havia um quê de respeito canônico pelo europeu no cosmopolitismo de Nabuco, coisa que tanto incômodo causaria nos participantes da Semana de Arte Moderna de 1922, por exemplo. Mas não se tratava de um respeito afetado, gratuito, acidental, que chegasse a impedir a relação ativa do personagem com sua época ou seu país. Tanto que, ao final da vida, quando se entrega às relações externas, não terá dificuldade em “trocar" a admiração pelas velhas potências europeias pelo elogio da nova potência norte-americana, a Europa pela América. Será uma conversão que ele entenderá como sendo uma exigência dos tempos e um modo de proteger as repúblicas do sul diante do velho imperialismo europeu e, ao mesmo tempo, mediante a união pan-americana, de diluir a força magnética exercida no subcontinente pelo Capitólio de Washington.

Há de fato mais de um Nabuco, mais de uma possibilidade de apresentar sua trajetória, mais de um modo de assimilar sua contribuição. Um pragmatista exacerbado lerá Nabuco como um político sensato, dado ao realismo e à ideia de política como arte do relativo. Um doutrinário, se for progressistae

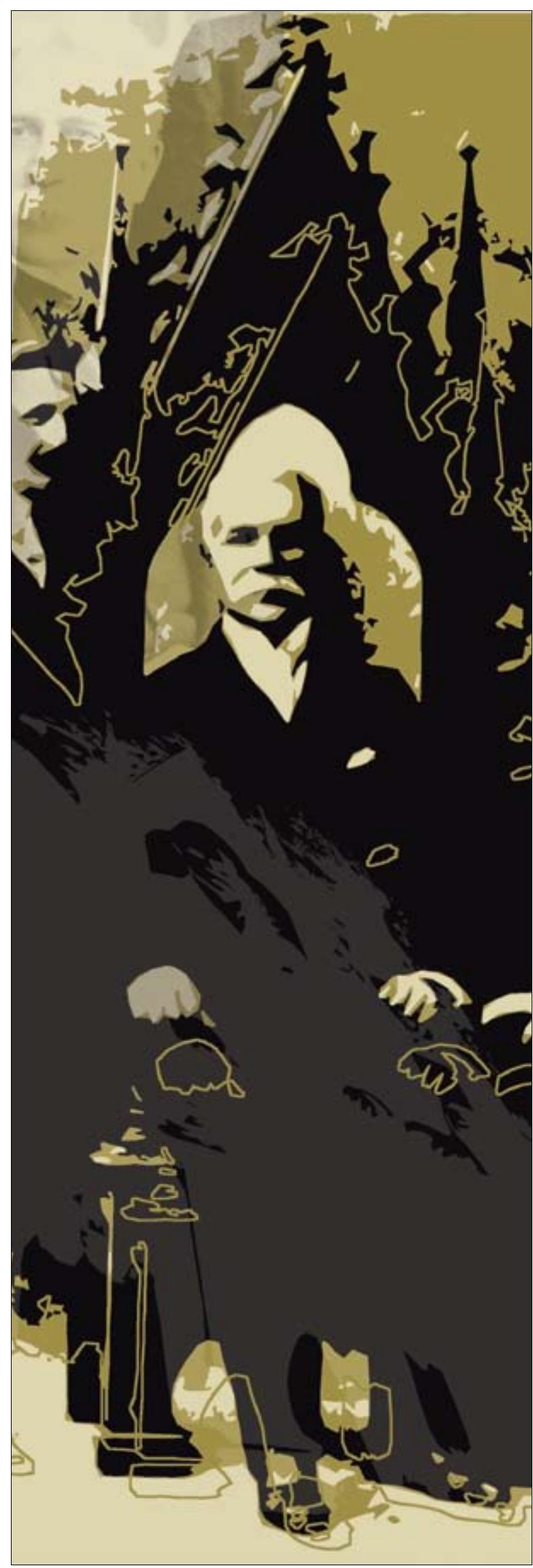


radical, não deixará de se fixar nos arroubos abolicionistas, no discurso incendiário dos anos 1880; se for conservador, seu Nabuco será o dos anos 1890, nostálgico das glórias monarquistas, ou o da primeira década do século XX, deslumbrado com o reencontro da religião e da fé. Há um Nabuco dos governantes, preso à suavidade do gesto e sempre propenso ao diálogo, e um Nabuco dos que pensam a política como um campode possibilidades que não dispensa o confronto, a crítica e o questionamento.

Mas Nabuco não é seguramente um conjunto de imagens fragmentadas que se negam ou se relacionam por antinomias. Em sua obra e em sua trajetória, algumas vigas mestras certamente se mantiveram, ajudando-o a saltar de uma fase a outra sem perdade substância, preservando o equilíbrio dinâmico da dialética estilização-realismo. Os múltiplos Nabucos não são prova de fragilidade ou inconsistência, menos ainda de desarticulação ou falta de harmonia e unidade. São, ao contrário, uma demonstração da capacidade que teve o intelectual de traduzir o ziguezaguear da realidade, de permanecer aberto para a revisão de posições e ligado às agendas e urgências de sua época. Somada à fineza de seu estilo e ao caráter envolvente de seu discurso, tal capacidade possibilitou a Nabuco emprestar vigor e poesia a todas as causas que abraçou.

\section{BIBLIOGRAFIA}

ALONSO, Angela. Joaquim Nabuco. Os Salões e as Ruas. São Paulo, Companhia das Letras, 2007.

LINS, Álvaro. O Barão do Rio Branco. Biografia Pessoal e História Política. 3a ed. São Paulo, Alfa-Omega/

Fundação Alexandre de Gusmão, 1996.

NABUCO, Carolina. A Vida de Joaquim Nabuco. 2 ${ }^{\text {a }}$ ed. São Paulo, Nacional, 1929.

NABUCO, Joaquim. Balmaceda. Rio de Janeiro/São Paulo, Nacional/Civilização Brasileira, 1937. .Pensamentos Soltos. São Paulo, Instituto Progresso Editorial, 1949a. . Escritos e Discursos Literários. São Paulo, Instituto Progresso Editorial, $1949 \mathrm{~b}$. . Cartas a Amigos. São Paulo, Instituto Progresso Editorial, 1949c, 2 volumes. . Um Estadista do Império. 4⿳a ed. Rio de Janeiro, Nova Aguilar, 1975. .Minha Formação. 9a ed. Brasília/Rio de Janeiro, José Olympio/INL, 1976. . O Abolicionismo. 6a ed. Petrópolis, Vozes, 2000. ."O Dever dos Monarquistas. Carta ao Almirante Jaceguay" [1895], in José Almino de

Alencar e Ana Pessoa (orgs.). Joaquim Nabuco: o Dever da Política. Rio de Janeiro, Edições Casa de Rui Barbosa, 2002.

. Diários 1873-1909. Prefácio e notas de Evaldo Cabral de Mello. Rio de Janeiro/Recife,

Bem-te-vi/ Massangana, 2005, 2 volumes.

NOGUEIRA, Marco Aurélio. As Desventuras do Liberalismo: Joaquim Nabuco, a Monarquia e a República.São Paulo, Paz e Terra, 1984.

."De Tensões, Dialéticas e Antinomias: o Encontro de Nabuco com a Política”, in Revista

Tempo Brasileiro, no 140, janeiro-março/2000, pp. 75-96.

.'O Abolicionismo", in Lourenço Dantas Motta (org.). Interpretação do Brasil: um Banquete

nos Trópicos. São Paulo, Senac, 2001, vol. 2, pp. 167-90.

. "Joaquim Nabuco na Era dos Impérios: 1870-1910", in Ciência \& Trópico, Recife, v. 31, nํ2,

2003-07, pp. 19-34.

SALLES, Ricardo. Joaquim Nabuco. Um Pensador do Império. Rio de Janeiro, Topbooks, 2002.

VIANA FILHO, Luiz. A Vida de Joaquim Nabuco. 2a ed. Rio de Janeiro, Martins-INL, 1973. 